\title{
A Short History of the W. P. Fraser Herbarium, University of Saskatchewan
}

by George W. Argus, Assistant Professor of Biology and Curator of the W. P. Fraser Herbarium

The herbarium of the University of Saskatchewan is the largest botanical collection in the province. It contains about 21,000 pressed and mounted plant specimens representing the flora of Saskatchewan and the surrounding prairie and boreal forest regions. Its present size and scope reflects the vision and energy of prairie naturalists who some $\mathbf{5 0}$ years ago sought to preserve a record of the flora of Saskatchewan, as well as the efforts of recent biologists and plant collectors. Its hisitory can best be traced by considering some of the individuals who were associated with it and their contributions to Saskatchewan botany.

The first plant collections made for the University are credited to T. N. Willing, a weed inspector, and, from 1910 to 1919, an Assistant Professor of Natural History. Willing's collections are not very numerous and today they represent a minor part of the herbarium.

At about the same time a plant pathologist, who was to become famous for his investigations on the stem rust of wheat, came to Saskatoon. William P. Fraser worked at the Dominion Laboratory of Plant Pathology (now the Canada Department of Agriculture Research Station, Plant Pathology Section) from 1917 to 1925 and in his spare time he began his first collection of Saskatchewan plants which was to become the nucleus of the herbarium of the Plant Pathology Section. However, it was in his capacity as a Professor of Biology, from 1925 to 1937, that Dr. Fraser started the University collection which now bears his name: The W. P. Fraser Herbarium. In addition to being a successful plant pathologist, Dr. Fraser was a naturalist who was interested in all the life around him and the native plants in particular. In his free time he collected, identified, mounted, catalogued, and studied the native plants of Saskatchewan. He was primarily interested in knowing what kind of plants occurred in Saskatchewan and where they grew. His interest was shared by colleagues, students, and amateurs all of whom drew from his store of knowledge about the native plants. Dr. Fraser's enthusiasm and boundless energy were an inspiration to many and several naturalists associated with him went on to publish their research on the flora of Saskatchewran. Three of these men can be singled out for their contributions to the W. P. Fraser Herbarium and to botany in Saskatchewan.

The first of these, Dr. R. C. Rus sell, was a friend and colleague of Dr. Fraser and their mutual interests in plant pathology and plant taxonomy spurred each of them to greater efforts. Dr. Russell taught Plant Taxonomy at the University for about 10 years after Dr. Fraser's retirement and, although now retired himself, he still adds specimens to the herbarium of the Plant Pathology Section which Fraser had started. They published several lists of the flora of Saskatchewan (Fraser and Russell, 1937, 1938,1944 ) culminating in a third revision largely compiled by Dr. Russell (Fraser and Russell, 1954) in cooperation with Drs. Ledingham and Coupland. Today these lists, which used Rydberg's nomenclature (1922, p. vii), are nomenclaturally out-dated and have been superseded by newer list (Breitung, 1957).

Mr. August J. Breitung was an amateur naturalist living at McKague, Saskatchewan, when he first came in contact with Dr. Fraser. $\mathrm{He}$ collected extensively and from 1934 to 1944 sent many of his plants to Fraser for identification, a service freely rendered by Fraser. This association stimulated Breitung's interest in the native flora and he became a well known collector of prairie and boreal forest plants. $\mathrm{He}$ has since published several papers dealing with the flora of the province including a list of the plants of central eastem Saskatchewan (1947), an account of the botany of the Cypress Hills (1954) and a catalogue of the vascular plants of Saskatchewan (1957). 
A third individual who was influenced by Fraser is Dr. George F. Ledingham, now a biologist-geneticist at the University of Saskatchewan, Regina Campus and editor of this journal. Ledingham was a student of Fraser's at, Saskatoon and the two made many collecting trips into the surrounding countryside. In 1943 he and Fraser collaborated on a study of the genus Carex (sedges) in the province (Fraser \& Ledingham, 1943). Dr. Ledingham has since become well known for his research on the cytogenetics of the Leguminosae (Pea Family), has established an herbarium at Regina and maintains a deep interest in the natural history of Saskatchewan.

After his retirement in 1937, Dr. Fraser devoted an increasing amount of time to his herbarium and greatly enlarged his collections. During these retirement years Fraser derived considerable saitisfaction from plant taxonomy and it was then that he was able to publish his research on the flora of Saskatchewan. It was noted by Professor Vanterpool (1944) that he visited his herbarium just a few days before his death in November, 1943. After Dr. Fraser's death his herbarium was little used for almost 11 years.

In 1949 Dr. R. T. Coupland started a small plant collection in connection with his research on the ecology of the native grasslands and the distribution of weeds in Saskatchewan. The value of the Fraser Herbarium was recognized by Dr. Coupland and in $1954 \mathrm{Dr}$. Rawson, Head of the Department of Biology; agreed to the temporary transfer of the herbarium to his care. At this time the W. P. Fraser Herbarium contained some 14,700 specimens. With the transfer of the Fraser Herbarium its development took a new direction. Now the collections were being made by biologists and their students who were studying the vegetation of Saskatchewan and knew the importance of preserving voucher specimens and the need for an authentically identified coliection of comparative specimens. Duplicates of most of the colleotions made at this time were sent to the herbarium of the Canada Department of Agriculture, Ottawa, for identification or verification and large sections of the herbarium were sent to specialists who checked thei identification. From 1949 to 196 more than 5,000 specimens, largel collected in connection with th Saskatchewan Weed Survey (1949 1955) were added to the Departmen of Plant Ecology Herbarium.

In 1961 the author, a plant taxon omist, came to the University as National Research Council Postdoc torate Fellow, and stayed on as Faculty member in the Department of Biology and Plant Ecology. Wit] the addition of a full time taxonomis to the staff, the herbarium becam an important research tool which re quired rapid, planned expansion. A this time interest was being centre on the boreal and subarctic region of Saskatchewan due, in part, to th establishment of the Institute fo Northern Studies and to new eco logical and taxonomic research inter ests. To facilitate this research pro gram there was an urgent need $t$ add plants from northern regions $t$ the herbarium. Since 1961 sever: large collections of plants from th boreal; subarctic and Arctic region have beer collected or received a exchange. Additions of special im portance include the collections $c$ Dr. Hugh M. Raup made along th Alaska Highway and in the North west Territories from the Gray Her barium, Arctic plants of the Hudso Bay region from the Natione Museum cf Canada; plants of Ontari and Carex of northwestern Canad and Alaska from the Canada Depart ment of Agriculture; collections mad by Dr. J. S. Maini, then of the De partment of Plant Ecology, in north ern Saskatchewan; and collection made by the author in the Lak Athabasca region and in the north eastern corner of Saskatchewar More than 6,000 specimens wer added to the W. P. Fraser Herbariun during these two years. These speci mens of the boreal and Arctic region not only contribute to current ecolo gical and taxonomic research bu make the herbarium a better bal anced collection of the entire flor of the province.

This emphasis on the flora 0 northern Saskatchewan does not re flect a lack of interest in the prairi regions. On the contrary, the prairi flora of Saskatchewan is still of grea interest and specimens are being col lected which will fill gaps in ou 
knowledge of the flora. Plants from southern Saskatchewan collected by Dr. B. Boivin of the Plant Research Institute, Ottawa, and those of several stucients in the Department of Plant Ecology have been added to the herbarium. In addition, exchange with the Rocky Mountain Herbarium at Laramie, Wyoming, has been initiated and exchange with other institutions on the Great Plains is contemplated.

As the herbarium grows the functions which it can perform will also grow. At the present time it serves as a representative sample of the flora of the province which may be borrowed by specialists studying a particular group of plants or by taxonomists working on the flora of central Canada. In addition it is used in teaching graduate and undergraduate students, as an aid in the identification of specimens, and as a place to preserve specimens studied in research projects. In the near future it will also serve as a source of materials for taxonomic and bhyto-geographic research, and hrough herbarium study taxonomic oroblems may be recognized and heir study initiated.

However, in order to achieve these ends and to serve the community in general, the herbarium needs the support not only of professional bioogists, but also of the amateur naturalists who are as important today as hey were in Dr. Fraser's day. Lange areas of Saskatchewan are poorly exolored botanically and the amateur, utilizing the techniques of the plant axonomist, can still make significant contributions to the knowledge of the lora of Saskatchewan. In future articles I plan to discuss techniques which should be used in collecting pecimens, the information which nust accompany each specimen, and low to receive help in preparing and dentifying specimens.

For the past 10 years the W. P. raser Herbarium and the Departnent of Plant Ecology Herbarium lave been housed as a single colleclon in the Crop Science Building, nd it is anticipated that they will emain itogether in the future. The reearch value of these collections is nhanced by their integration and the pirit of co-operation which it eflects bodes well for the future of plant taxonomy at the University of Saskatchewran and for the W. P. Fraser Herbarium.

\section{REFERENCES}

Breitıng, A. J. 1947. Catalogue of the vascular plants of central eastern Saskatchewan. Can. Field-Nat. 61:71-100.

1954. A botanical survey of the Cypress Hills. Can. Field-Nat. 68:55-92.

1957. Annotated catalogue of the vascular flora of Saskatchewan. Am. Midl. Nat. 58:1-72.

Fraser, W. P. 1940. Notes on the Cyperaceae of Saskatchewan. I. Scirpus. Can. FieldNat. 54:100-101.

1942. Notes on the willows of Saskatchewan. Can. Field-Nat. 56:104-110.

and G. F. Ledingham. 1943. Notes on the Cyperaceae of Saskatchewan. II. Carex. Am. Midl. Nat. 29:42-50.

- and R. C. Russell. 1937. List of the flowering plants, ferns, and fern allies of Saskatchewan. Univ. of Sask. 46 pp. \& \& 1938. Additions to the list of flowering plants of Saskatchewan. Univ. of Sask., mimeographed.

\& 1944 . A revised, annotated list of the plants of Saskatchewan. Univ. of Sask. 64 pp.

- \& 1954. An annotated list of the plants of Saskatchewan. Revised by R. C. Russell, G. F. Ledingham, and R. T. Coupland.' Univ. of Sask. 50 pp.

Rydberg, P. A. 1922. Flora of the Rocky Mountains and Adjacent Plains, second ed. New York.

Vanterpool, T. C. 1944. William Pollock Fraser, 1867-1943. Mycologia 36:313-317.

\section{CALL FOR ISSUES OF BLUE JAY FOR THE LIBRARY OF THE UNIVERSITY OF ALBERTA IN CALGARY}

It has come to our notice that the Library of the Calgary Campus of the University of Alberta is in dire need of a set of the Blue Jay. Would anyone who could spare any number of issues of Blue Jay (and particularly the earlier issues or volumes) please be so kind as to write to Dr. M. T. Myres, Dept. of Biology, University of Alberta (Calgary), Calgary, Alberta, indicating what they can offer. It is most desirable that all institutions of higher learning on the prairies should be equipped with as complete sets as possible of our journal, so anyone who can assist the University of Alberta, Calgary, to achieve this objective can be assured that whatever they can give will be greatly appreciated and will be put to good use in training and in assisting research in natural history. 